\title{
ENGLISH PERFECT IN COGNITION OF SLOVAK ISCED3 LEARNERS OF ENGLISH - PRELIMINARY EMPIRICAL EVIDENCE
}

\author{
Tomáš Hlava ${ }^{1}$
}

\begin{abstract}
In English language instruction in Slovakia, a strong preference for declarative knowledge at the expense of procedural knowledge development has been reported over the last two decades. However, the cognitive aspects of language attainment predict no impact of instructional efforts, since mental representations of language to be attained are told to be supported by different cognitive systems than associative learning develops. Language variation materializes differences among languages based on differences in digitalizing the experience and thus understanding the world. For Slovak learners, the English present perfect is one such anomaly in categorization. This paper aims to answer what the specific interactions between past simple and present perfect are and how the predicted cognitive aspects of language attainment influence the use of different types of knowledge. A proficiency test focusing on declarative knowledge and language use without context and in context was distributed to 600 Slovak learners of English at the ISCED3a level. In Past simple conditions, students proved highly proficiency in all 3 types of tasks. In present perfect conditions, declarative knowledge strongly dominated over language use in context. In Present perfect conditions, substitutions by past simple were significantly more frequent than substitutions of present perfect by past simple. Cognitive funneling was recognized as a process inhibiting fast proceduralization of the English present perfect compared to fast and reliable proceduralization of the past simple.
\end{abstract}

UDC Classification: 373, DOI: 10.12955/cbup.v7.1397

Keywords: present perfect, tense, aspect, language learning

\section{Introduction}

Rather complex are the background (or underground) workings of any particular natural language, whether theoretically underpinned by statistical inferences of emergentists, procedural knowledge of skill-theorists, mental representation of generativists or the declarative knowledge of the Piagetian school of thought. What we perceive with our senses in its material form carries the information to be decoded in the form of surface structures, if you will, and all that thanks to one simple fact: the computational power and conceptual capacity of the human mind allows for it. Disregarding the clash of nativists and socio-cultural theorists, learning a second or foreign language poses an ultimate test. In this case it is the human mind that becomes a testee and the while above mentioned capacity plays in favour of a language learner, individual differences hand in hand with cross-linguistic variation play against it, resulting in 'inter-learner and intra-learner differential success' (Han, 2014:49). The results of these 'tests' are at best mixed. Beside the cases of learners whose target language grammar was considered in a crucial way defective (e.g. Schmid, 1983; Schumann, 1978), instances of almost nativelike language performance have been documented as well (e.g. Ioup et al., 1994). The observed differences in the language attainment of individuals (in terms of correct use of the target language grammar) were already discussed by Selinker (1972) in his concept of interlanguage which remains ingame to date by VanPatten's proposal that 'the mental representation of [second / foreign] language is largely unaffected by instructional efforts directed at the formal properties of a language' (2014:106). The very same position is held by Paradis (1994a, 2004, 2009), who is supporting the so called 'nointerface theory' (associated with Krashen's learning/acquisition hypothesis) disallowing associatively learned declarative knowledge to neither communicate with nor transform into the procedural type of knowledge; or Ullman $(2001,2004,2016)$ offering neuro-physiological evidence supporting the declarative-procedural distinction. The other side of the barricade is occupied by the proponents of 'strong-interface theory' allowing the communication between declarative and procedural systems or even transformation of associatively learned data into the form of procedural knowledge (DeKeyser 2007a, 2007b, 2008, 2011; Johnson 1996). Being spread among Slovak scholars and teachers-to-be for almost two decades, the latter position known under the term 'proceduralisation' (de sensu Anderson) is based on the interpretation of Anderson's ACT-R theories (1983, 1994, 2012). However, confusion might arise when studying proponents of no-interface theories, understanding it only as a 'speed-up' in the series of mental mechanisms utilizing exclusively the declarative path of data processing (de sensu Paradis), while the automatic language processing (exploiting mental representations of language mentioned by VanPatten above) remains untouched. Disunion in an elementary theoretical position as this one creates enough room for misunderstanding and speculation. An example of one such false interpretation could be the following: if there is no impact of explicit formal instruction on language representation, then abandon it totally and the mental representations will eventually take care of

\footnotetext{
${ }^{1}$ Faculty of Education, Comenius University in Bratislava, Slovakia, hlavaxxii@uniba.sk
} 
themselves. Unfortunately (or fortunately?), Ellis (1997) as well as Harley (2012) offered meta-analyses based on studies concluding the effectiveness of immersion-programs and claimed participants had a very high level of fluency at the expense of grammatical accuracy. In a similar vein, Šipošová shares the idea of Spada claiming that 'the thought that Communicative Language Teaching (CLT) means an exclusive focus on meaning is a myth or a misconception' (Spada 2007 in Šipošová, this edition). Grammar instruction should thus not be seen as a meaningless activity contradicting the mechanisms of language attainment, but rather the opposite - as an activity supporting language attainment, although indirectly - by allowing the creation of associative declarative knowledge covering the gap in procedural knowledge until the time it is created and ready to use. This view is also supported by Ullman (2002) stating that the process of skill acquisition from the large volumes of relatively quickly learned declarative knowledge towards the states in which consciously undemanding, procedural, analogies of declarative contents substitute the original structures one by one is natural. Moreover, even Anderson and Fincham (1994), the pioneers of 'proceduralisation' being understood as a transformation of declarative knowledge to procedural, suggest that the procedural pathway is not bound to the previous creation of declarative knowledge. Otherwise, logically, first language acquisition would not be possible. How is it then, that while the attainment of a native language in an intact human is unproblematic, attainment of another language does not necessarily meet with success? Individual differences - reasons internal to the learner, or materialized within the learner, if you will, are out of the scope of this work, but what the ideas in this work stem from is the manifestation of cross-linguistic variation in language learners' cognition - reasons external to the learner (although it is true that any foreign language distinct from the mother-tongue must be necessarily processed internally, where it is subject to individual differences projected as intra-learner differential success).

Cross-linguistic variation is a fact grounded in the findings of language typologists offering endless and very detailed descriptions of accessible human languages, but what exactly is the root of linguistic variation and why does it pose such a strong constraint on foreign language attainment? The extralinguistic world is too complex for living organisms to cope with and language is long considered to be the cognitive gadget and platform reducing this burden through the 'digitalization of incoming [otherwise analogue] perceptions' (Sokol 2007:30). This process is understood as a 'reduction of complexity ... a basic learning process ... by which human children [but not only children, of course] learn to cope with the overwhelming mass of information and experience' (Sokol, 2007:30). A digital system of signs thus allows language users to understand the extralingual phenomena artificially categorized into distinct classes, disregarding their concrete or abstract origin. To continue with the thoughts of Sokol, there is one more idea directly inviting the issue of time, tense and aspect to the scene. Language is, naturally, a means of communication, but 'long before language can serve as a means of communication, it has to serve to organize experience [in time], to build up a viable world in which a human being can orient himself or herself [by means of tense and aspect]' (Sokol, 2007:31). Tense and aspect are the (secondary) grammatical categories of verb, which in itself categorizes (as a primary grammatical category) for semantic contents representing actions or states and changes they undergo, through which a single flow of time with all the happenings can be interpreted. Apparently, different language groups digitalize the continuous unfolding of stream of time slightly differently because 'if time is naturally divided into three segments and language makes reference to those segments, it generally does not do so in any simple or universal fashion' (Binnick, 1991:127) Moreover, in genetically related language communities, what was once a diachronically shared grammatical sign can in one language undergo a change in function or it can lose its presence while the function is either lost or it becomes covered by some other sign. All this allows for cross-linguistic variation that in the materialized form represents the result of the way members of the language community categorize, and therefore understand, the world; for subtle peculiarities in tense / aspect systems of human languages. Hence, this study covers the issues of how Slovak learners of English exploit the tense / aspect system of the English language, what are the specific interactions between past simple and present perfect and how the predicted cognitive aspects of language attainment influence the use of different types of knowledge.

\section{Perfect tense in English and Slovak}

Traditionally, the grammatical category of aspect and tense 'have been viewed as two complementary facets of one set of phenomena' (Binnick, 1991:ix) but besides the more modern concepts introduced, 
like 'status' or 'phase', there is also a third traditional member of the system - mood, a category that complementizes the so called TAM (from Tense-Aspect-Mood) system (e.g. Dahl, 1985). For the sake of simplicity, this work will be kept in the realm of tense / aspect interaction and even then it will still pose certain difficulties while dealing with English perfect, since as Declerck (1994:157) writes, 'the English present perfect is a notorious problem in the literature on tense and aspect. For one thing, the linguistic world is divided on the question whether the present perfect is a tense or an aspect, or neither. For another, there is no consensus whatsoever as regards the semantics of the construction and the number of different usage types'.

As for the former, a long-lasting period of diverging ideas and uncertainty is persistent ${ }^{2}$. Since the meaning of modern perfect ${ }^{3}$ lies in expressing 'continuing present relevance of a past situation ... [the] difference between the perfect and the other aspects has led many linguists to doubt whether the perfect should be considered an aspect at all' (Comrie, 1976:52). The reason, as Comrie (ibid) argues is 'that the perfect is rather different from these aspects, since it tells us nothing directly about the situation in itself'. This problem is best described by what is probably one of the Comrie's (1976:52) most quoted thoughts: 'it [perfect] is an aspect in a rather different sense [than] the other aspects'. Next, the problem of recognizing the English present perfect as either past of non-past tense is important for two reasons. First, cases of pedagogical grammar explaining EPP in terms of past tense are not rare. This view most probably stems from explaining EPP from the functional perspective and that is expressing the meanings occurring in the indefinite past time - therefore the linkage to past tense. An example of such an approach was found in the analysis of the perfect in spoken British English by Bowie, Wallis \& Aarts (2013:328) who defined 'tensed, past-marked VPs ... as tensed VPs marked for past either morphologically or with the perfect, or both. By 'marked for past' we mean formal marking, involving forms characteristically used to indicate pastness or anteriority'. However, Elsness (1997:2), as well as many other theorists, understands 'the present perfect as in some way being more closely linked with present time than the preterite. This is sometimes related to the structure of the present perfect, the present-tense auxiliary...'. Similarly, Hewson \& Bubenik (1997:1) write that there is 'a confusion between what is represented (the event taking place in time) and the means of representation (the linguistic category)'. Consequently, ignoring the morphological and systemic evidence inevitably leads to a certain amount of error and confusion (ibid). Moreover, learners of English are told that (present) perfect constructions are not part of the Slovak language system. On the one hand, this is in accordance with Oravec at al. (1984) where the mention of perfect cannot be found neither under the topic 'Slovesný vid' (verbal aspect) nor 'Slovesný čas' (verbal tense). On the other hand, Načeva-Marvanová (2010:18) recognizes 'Slavic perfect' as a well-established have + past (passive) participle construction allowing speakers of Czech to produce sentences structurally identical to EPP (Eng.: I have already read that book. - Czech: Tu knihu mám již prečtenou.) what should apply in the same way to the Slovak language (since both languages are very close relatives and sentences such as Tú knihu mám už prečitanú.; Eng.: I have broken my leg. - Mám zlomenú nohu.; Eng.: Have you brushed your teeth already? - Máš už vyčistené zuby? are grammatical Slovak sentences). Second, as Hais (2006:182) writes, EPP constructions are translated into Slovak language usually as a past (simple) tense what is in accordance with Oravec et al. (1984:148) stating that the meaning of perfective verbs with their resulting state stretching up to the present (notice its similarity to one of EPP meanings - stative perfect) is structurally covered by preterite (Eng. I have bought new shoes. - Slovak Kúpil som si nové topánky.). Exceptional are cases of translating positive sentence types with universal perfect meaning, in which case present tense is used (Eng. How long have you been waiting? - Slovak. Ako dlho uz čakáš?). Also, it is necessary to admit that in the majority of Slovak translations of EPP sentences, preterite cannot be substituted by Slavic H-perfect. As for the latter, we stay conservative and follow the four-fold distinction based on the 'McCawley's tradition' (1971), namely: stative, existential, universal and 'hot news' perfect. There is a rough one-to-one correspondence to Comrie's (1976) terminology: perfect of result / experiential perfect / perfect of persistent situation / perfect of recent past. Some other 'visualizations' of the meaning

\footnotetext{
${ }^{2}$ compare the understanding of aspect by Binnick (1991:128) and Comrie (1976:5). Based on how individual authors understand objectivity and subjectivity of tense and aspect, they present rather contrasting ideas.

${ }^{3}$ compare current understanding of perfect with its original function expressing the meanings now covered by what modern linguistics calls 'preterite'
} 
of English perfect can be found as well, such as Dirven's (2007) inferential perfect corresponding to experiential perfect and continuative perfect corresponding to the perfect of result.

Based on the survey of Slovak students' opinions of their own English language performance (Hlava, 2018), Figure 1 shows that relative difficulty of 'present perfect' is higher than the relative difficulty of past simple. The number of students who opine (1) their theoretical understanding (red line at the top) and (2) use it in communication (green line at the top) flawlessly differs in case of items 'present perfect' (PrP) and past simple (Ps) even by visual inspection. Reversal shape was observed in the number of students who consider their (1) and (2) as not being flawless.

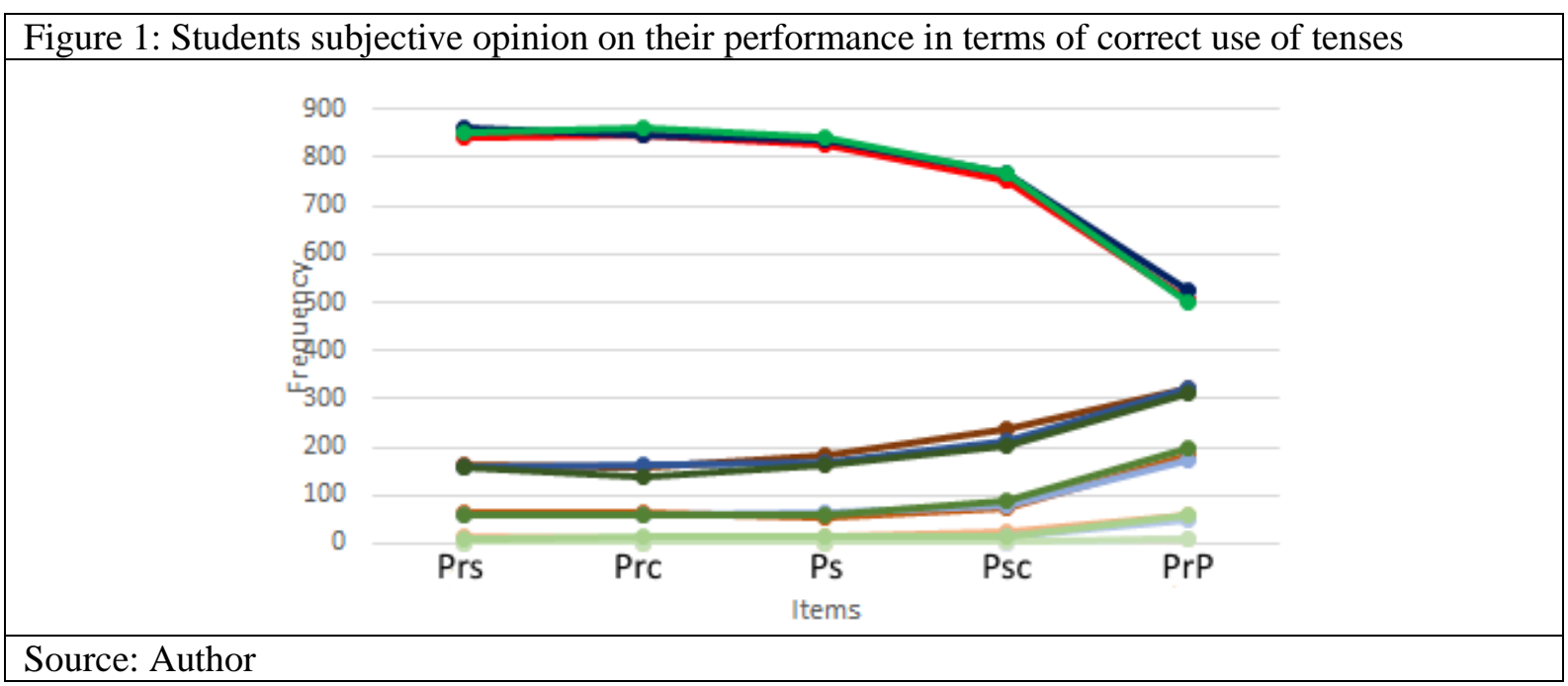

The indication that students have a problem with the use of EPP supports the findings of theoretical description of English and Slovak tense / aspect system and cognitive aspects of foreign language attainment. To test its relevance empirically, the following hypotheses were constructed.

1. There is no difference in correct use of pasts simple based on task type.

2. There is no difference in correct use of present perfect based on task type.

3. There is no difference in substituting Ps with PrP, and PrP with Ps based on task type.

4. There is no difference in the use of incorrect variant and invariant tense forms.

\section{Method}

Participants

Learners $(n=600)$ of ISCED3a category in their last and penultimate year of study, all were Slovak natives learning English as a foreign language. This sample had a non-probability character - a purposive and convenient sampling method was applied. Thus, the gathered data came from learners whose teachers agreed on their cooperation; schools that approached students are situated in various regions of Slovakia. All participants were intact, with normal cognitive development.

\section{Research tool}

The architecture of the distributed proficiency test (B1, CEFR) was based on 3 tasks aimed at measuring 3 typologically different types of knowledge, namely (a) declarative knowledge, (b) knowledge of language use without context (mechanical manipulation with language), and (c) knowledge of language used in context.

Task (a) consisted of 10 statements - descriptions of the most central use of the past simple (Ps - 3 statements), past continuous ( $\mathrm{Pc}-3$ statements), present perfect ( $\mathrm{PrP}-3$ statements) and one extra statement not fitting any of previously mentioned tenses. Respondents were asked to sort the statements based on what tense / aspect they were description of.

Task (b) consisted of 10 items - sentences in various tense / aspect variations (one sentence with one possible solution). Two sentences obligatorily required past tense, two sentences obligatorily required present perfect, the other 6 sentences functioned as distractors. Respondents were asked to put the offered verb into the correct tense / aspect variation.

Task (c) consisted of 25 items - sentences in various tense / aspect variations (one sentence with one possible solution). Seven sentences obligatorily required past simple, eight sentences obligatorily 
required present perfect. The other sentences were fillers. This time, the sentences were not randomly selected but they offered a meaningful whole creating a contextualised environment for the appropriate language use.

Respondents were asked to put the offered verb into correct tense / aspect variation.

\section{Results and discussion}

Results

First, the correctness of answers for Ps by task type was analyzed. A chi2 test of independence was calculated comparing the frequencies of correct and incorrect answers in 3 different types of tasks ( $a, b$, c). A significant interaction was found. Students were significantly more likely to answer correctly in task type (b) than task type (a); in task type (c) than in task type (a). No significant difference was found in correctness between task type (b) and (c).

$$
\begin{array}{ll}
\mathrm{a} / \mathrm{b} / \mathrm{c} & (\mathrm{X} 2(2)=184.924, \mathrm{p}<.05) \\
\mathrm{a} / \mathrm{b} & (\mathrm{X} 2(1)=71.661, \mathrm{p}<.05) ; \\
\mathrm{a} / \mathrm{c} & (\mathrm{X} 2(1)=153.888, \mathrm{p}<.05) ; \\
\mathrm{b} / \mathrm{c} & (\mathrm{X} 2(1)=1.605, \mathrm{p}<.05) ;
\end{array}
$$

We reject the null hypothesis, that the correctness of student's answers is independent of the task type in $(\mathrm{a}, \mathrm{b} ; \mathrm{a}, \mathrm{c})$ dyads.

Second, the correctness of answers for PrP by task type was analyzed. A chi 2 test of independence was calculated comparing the frequencies of correct and incorrect answers in 3 different types of tasks (a, b, c). A significant interaction was found. Students were significantly more likely to answer correctly in task type (a) than task type (b); in task type (a) than in task type (c) as well as in task type (b) than in task type (c).

$$
\begin{array}{ll}
\mathrm{a} / \mathrm{b} / \mathrm{c} & (\mathrm{X} 2(2)=688.548, \mathrm{p}<.05) \\
\mathrm{a} / \mathrm{b} & (\mathrm{X} 2(1)=61.678, \mathrm{p}<.05) ; \\
\mathrm{a} / \mathrm{c} & (\mathrm{X} 2(1)=624.139, \mathrm{p}<.05) ; \\
\mathrm{b} / \mathrm{c} & (\mathrm{X} 2(1)=174.820, \mathrm{p}<.05) ;
\end{array}
$$

We reject the null hypothesis, that correctness of student's answers is independent of the task type.

Next, the correctness of answers by 'tense' was analyzed, considering the variant form of 'tense'. A chi2 test of independence was calculated for all 3 types of tasks ( $a, b, c)$ comparing the frequency of correct answers in past simple tense and present perfect. A significant interaction was found in task types (b), (c). In task (c) Students were significantly more likely to substitute obligatory PrP verb form by Ps verb form (56.34\%) than Ps verb form by PrP verb form (4,57\%). In type (a) task, no significant differences were observed - student's substitution of PrP by Ps and vice versa was by chance.

$$
\begin{array}{ll}
\text { (a) } & (\mathrm{X} 2(1)=4.490, \mathrm{p}<.05) \\
\text { (b) } & (\mathrm{X} 2(1)=212.701, \mathrm{p}<.05) \\
\text { (c) } & (\mathrm{X} 2(1)=1950.775, \mathrm{p}<.05)
\end{array}
$$

We reject the null hypothesis that correctness of student's answer in task type (b), (c) is independent of 'tense' type.

Last, the incorrectness of answers by 'tense' was analyzed. A chi2 test of independence was calculated for task type (c) comparing the frequency of incorrect answers of variant type (Ps and PrP respectively) and invariant type (sums of all possible 'tenses'). A significant interaction was found $(\mathrm{X} 2(1)=200.812$, $\mathrm{p}<.05)$. Students substituted the obligatory PrP verb form by Ps verb form significantly more often (60.98\%) than the possible 'tensed' verb form other than Ps (39.01\%). However, the Ps verb form was substituted by PrP significantly less often $(27.56 \%)$ than by the possible 'tensed' verb form other than $\operatorname{PrP}(72.43 \%)$.

\section{Discussion}

In terms of past simple, the way Slovak students subjectively described their EPP use is partially in accordance with their performance in test tasks. Slovak students performed more successfully in decontextualized (b) and contextualized (c) tasks compared to a declarative knowledge task (a). Although it is claimed (Lojová - Kostelníková 2014, Lojová 2015) that language instruction in Slovakia is oriented on DEC, this finding is surprisingly contradictory, and it is possible to understand it as a sign of shift from DEC oriented instruction towards more PRO oriented instruction. However, in task (a), 
statement ' $b$ ' ('It is used to express human experience') categorized as describing the use of EPP in its experiential meaning was the most frequent incorrect answer. Past time is seen as known / factual reality. Hence, beside present perfect used experientially (My mom's boss has been to Tokyo twice - so he wants her to go there too and enjoy the atmosphere; I have broken my leg twice - so I know how it limits you) the past simple tense inherently covers both situations that happened 'before now' and when one was not involved in them in any way (My mom's boss broke his leg yesterday) as well as situations one was involved in (I broke my leg yesterday) and thus experienced them himself. Therefore, the formulation of item ' $b$ ' seems to involve the semantic meaning applicable to Ps, thus resulting in lowered success-rate for Past tense category in task (a). Otherwise, performance in task (b) and (c) does not indicate cognitive constraints posed on the proceduralization of past simple tense systematically preventing respondents from answering correctly. As such, the similarity of both tense systems in terms of Ps-Ps interaction provides quick and easy acquisition of the English language counterpart to Slovak past tense. Moreover, if statement ' $b$ ' does not influence the results as stated above, the power of this claim is even stronger as far as the use of associatively learned language facts (less successful) could not be the source supporting the performance in task (c). Acquisition of English Ps thus did not prove unsuccessful.

In terms of present perfect, the way Slovak students subjectively described their EPP use is in accordance with their performance in test tasks. In this case, the suggested substantial distinctness between mental representations of language and DEC type of knowledge obtained through language instruction was not falsified. Compared to the finding about Ps simple, Slovak learners are unsuccessful in its use in context. As described in the theoretical part, English tense/aspect system categorizes for past events impacting the present situation differently and the cognitive setting of Slovak learners does not adapt as fast, easily and reliably as it does with Ps. In detail, the interaction between EPP and Ps in terms of their substitution reflects 'cognitive funneling', and not allowing the automatic subconscious splitting of two functions (preterite+perfect meanings) generally singularized in one Slovak form (Ps) into two functions (preterite/perfect meaning) represented by two distinct forms (Ps / EPP) in English. While students understand the EPP function both conceptually (because it is incorporated in the semantics of Slovak perfect) and formally (correctness in task (a)), the results do not falsify the cognitive bias towards the form expressing resultant/perfect meaning in their native language (Ps). Taken from the other end, students do not 'funnel' towards the EPP forms in Ps contexts, as the preterite and perfect meanings are merged into one structure (Ps). Although the Slavic perfect form is existent, its' presence in Slovak language seems to be marginalized, marked and thus cognitively interpreted as irrelevant remaining unreferred to. Evidence comes from the observation that Slovak students understand the differences in use of EPP and Ps but as they have no access, these language facts (DEC) do not intervene. The process of automatized 'cognitive funneling' is consequently resolving the form/function problem based on an already interiorized understanding of the world through a digitalized set of categories imposed by one's native language.

\section{Conclusion}

The theoretically posed suggestion that associatively learned language facts do not impact the mental representations of foreign/second language were not falsified. Both sets of declarative and procedural knowledge proved reliable in conditions allowing for the analogy based on digitalized understanding of the world through language categories of native language. Procedural knowledge behaved unreliably in conditions when cognitive funneling based on understanding the world through the categories of native language was preventing acquisition to be as fast as in the case of categories through which both languages interpret the world identically/similarly. In such condition, a set of declarative knowledge was found reliable. As for the practical significance, cognitive funneling in terms of English present perfect and Past simple interaction raises further issues about the syntactic-semantic role of English and Slovak verbs 'have'/'mat' and their impact on the processing of the English language by Slovak learners.

\section{Acknowledgment}

This article is an output of the project VEGA 1/0495/17 The interrelation between mental representations of the English language system, performance in metalinguistic tasks and production in communicative situations in English language teaching. 


\section{References}

Anderson, J. R. \& Fincham, J. K. (1994). Acquisition of procedural skills from examples. Journal of Experimental Psychology: Learning, Memory and Cognition. 20, 1322-1340.

Anderson, J. R. (1983). The Architecture of Cognition. Cambridge, MA: Harvard University Press.

Anderson, J. R., Lebiere, Ch. (2012). The Atomic Components of Thought. New York, : Psychology Press.

Binnick, R. (1991). Time and the Verb. Cambridge, NY: Cambridge University Press.

Bowie, J., Wallis, S., Aarts, B. (2013). The perfect in spoken English. In Aarts, B., et al. (Eds.), The Verb Phrase in English. (pp. 318-350), New York, NY: Cambridge University Press.

Comrie, B. (1976). Aspect. Cambridge, UK: Cambridge University Press.

Dahl, O. (1985). Tense and Aspect Systems. New York, NY: Basil Blackwell.

Declerck, R. (1994). The present perfect and the English tense system. In Draye, L. (Ed.), Leuven contributions in linguistics and philology. 83(2), (pp. 157-180). Leuven, Belgium: Peeters Publishers.

Dirven, R., Radden, G. (2007). Cognitive English Grammar. Amsterdam, Netherlands: John Benjamins.

DeKeyser R. M. (2008). Introduction: Situating the concept of practice. In DeKeyser, R. M. (Ed.), Practice in a Second Language. (pp. 1-18), Cambridge, UK: Cambridge Uuniversitz Press.

DeKeyser, R. M. (2007a). Automaticity and automatization. In Robinson, P. (Ed.), Cognition in a Second Language instruction. (pp. 125-151), Cambridge, UK: Cambridge University Press.

DeKeyser, R. M. (2007b). Skill Acquisition Theory. In Theories in Second Language Acquisition. (pp. 94-112), New Jersey, NY: Routledge.

DeKeyser, R. M. (2011). Cognitive-Psychological Processes in Second Language Learning. In Long, M. H., Doughty, C. J. (Eds.), The Handbook of Language Teaching. (pp. 119-138), West Sussex, UK: Wiley-Blackwell.

Dornyei, Z. (2009). The Psychology of Second Language Acquisition. Oxford, UK: Oxford University Press.

Ellis, R. (1997). SLA Research and Language Teaching. Oxford, UK: Oxford University Press.

Elsness, J. (1997). The Perfect and the Preterite in Contemporary and Earlier English. In Wekker, H. (Ed.), Topics in English Linguistics, 21, Berlin: De Gruyter.

Han, Z.-H. (2014). From Julie to Wes to Alberto: Revisiting the construct of fossilization. In Han, Z.-H., Tarone, E. (Eds.), Interlanguage. Forty years later., (pp. 48-74). Amsterdam, Netherlands : John Benjamins.

Harley, B. (2012). The role of focus-on-form tasks in promoting child L2 acquisition. In Doughty, C., Williams, J. (Eds.), Focus on Form in Classroom Second Language Acquisition, Cambridge, UK: Cambridge University Press.

Heis, K. (2006). Anglická gramatika. [English grammar]. Bratislava, Slovakia: SPN.

Hewson, J., Bubenik, V. (1997). Tense and Aspect in Indo-European Languages. In Koerner Konrad, E. F. (Ed.), Current Issues in Linguistic Theory, 145, Amsterdam, Netherlands: John Benjamins.

Ioup, G., Boustagui, E., El Tigi, M. \& Moselle, M. (1994). Reexamining the critical period hypothesis: A case study of successful adult SLA in a naturalistic environment. Studies in Second Language Acquisition, 16(1), 73-98.

Johnson, K. (1996). Language Teaching and Skill Learning. Oxford, UK: Blackwell.

Lojová, G. - Kostelníková, M. (2014). Enhancing the Effectiveness of Teaching EFL Grammar in Slovakia. In Lojová, G., Vajíčková, M., Kostelníková, M. (Eds.), Studies in Foreign Language Education, 6, Nümbrecht, Germanz: Kirsch-Verlag. Lojová, G. (2015). Deklarativne a procedurálne vedomosti vo výučbe anglického jazyka. Bratislava, Slovakia: UK v Bratislave.

Načeva-Marvanová, M. (2010). Perfektum v současné češtině. [Perfect in contemporary Czech]. In Čermák, F., Kučera, K., Petkevič, V. (Eds.), Studie z korpusové lingvistiky [Studies in corpus linguistics]. 11, Prague, Czech Republic: Nakladatelsví Lidové noviny.

Oravec, J., Bajzíková, E., Furdík, J. (1984). Súčasný slovenský spisovný jazyk. [Current standard Slovak language], Bratislava, Slovakia: Slovenské Pedagogické Nakladatel'stvo.

Sokol, J. (2007). Language and experience. In Fehr, J., Kouba, P. (Eds.), Dynamic structure-language as an open systém. (pp. 27-35), Prague, Czech Republic: Litteraria Pragensia.

Ullman, T. (2016). The Declarative/Procedural Model: A Neurobiological Model of Language Learning, Knowledge, and Use. In Hickok, G. - Small, S.L. (Eds.), Neurobiology of Language, (pp. 953-968), Academic Press. 